\title{
Aktywność chemoprewencyjna flufenazyny i jej analogów w hodowlach ludzkich limfocytów preinkubowanych z inhibitorem syntetazy ceramidowej
}

\author{
Agata Jaszczyszyn ${ }^{1}$, Kazimierz Gąsiorowski ${ }^{1}$, Piotr Świątek², \\ Wiesław Malinka², Urszula Kaziród ${ }^{3}$
}

\begin{abstract}
Wstęp. Ceramid (cer) jest zazwyczaj produkowany na drodze hydrolizy sfingomieliny przez sfingomielinazy (SMase). Zbadano, że aktywność chemoprewencyjna — propoptotyczna i chemouwrażliwiająca — piperazynowej pochodnej fenotiazyny (Pht), flufenazyny (FPh) i jej nowo syntezowanych analogów — związków 1b i 3f — zależy od stymulacji lizosomalnej, kwaśnej sfingomielinazy (aSMase), niezależnej od Zn ${ }^{2+}$,jednego z enzymów uczestniczących w powstawaniu endogennego cer. Innym ważnym_szlakiem tworzenia cer w komórce jest synteza de novo z udziałem syntetazy ceramidowej (CerS). Celem pracy była ocena aktywności chemoprewencyjnej FPh i jej analogów: związków 1b i 3f po nieodwracalnym zablokowaniu CerS.

Materiał i metody. Aktywność chemoprewencyjną badanych związków (10 $\mu \mathrm{M}, 2$ godz.) oceniano w hodowlach limfocytów ludzkich uszkodzonych genotoksycznie przez inkubację z benzo[a]pirenem (+B[a]P; 7,5 $\mu \mathrm{M}, 48$ godz.) i po preinkubacji z selektywnym inhibitorem CerS — fumonizyną $\mathrm{B}_{1}\left(+\mathrm{FB}_{1} ; 20 \mu \mathrm{M}, 1,5 \mathrm{godz}\right.$.). W ocenie efektów badanych związków zastosowano metody: mikroskopii fluorescencyjnej, spektrofotometrii i spektrofluorymetrii. Istotność statystyczną uzyskanych rezultatów sprawdzono za pomocą testu $t$-Studenta.

Wyniki. W hodowlach limfocytów w obecności inhibitora CerS $\left(+\mathrm{B}[\mathrm{a}] \mathrm{P} ;+\mathrm{FB}_{1}\right)$ inkubacja hodowli z analogami $1 \mathrm{~b}$ i $3 f$ prowadziła do istotnie niższego $(\mathrm{p}<0,05)$ odsetka komórek w apoptozie i akumulacji rodaminy 123 (Rod-123) w porównaniu z hodowlą bez inhibitora CerS (+B $\left.[a] \mathrm{P} ;-\mathrm{FB}_{1}\right)$. W przypadku macierzystego związku FPh wpływ na hodowle limfocytów nie zależał od obecności inhibitora CerS.

Wnioski. Efekty proapoptotyczny i chemouwrażliwiający analogów 1 b i 3f są uwarunkowane aktywacją CerS. Natomiast dla macierzystej FPh wykazano, że jej aktywność chemoprewencyjna nie zależy od stymulacji szlaku syntezy de novo cer z udziałem CerS.
\end{abstract}

\section{Chemopreventive activity of fluphenazine and its analogues in human lymphocyte cultures} preincubated with ceramide synthase inhibitor

Introduction. The ceramide (cer) is generated mainly via hydrolysis of sphingomyelin by sphingomeylinase (SMase). It was previously documented that chemopreventive activity - proapoptotic and chemosensitizng of piperazine phenothiazine derivative, fluphenazine (FPh) and its newly synthesized analogues, $1 \mathrm{~b}$ and $3 \mathrm{f}$ compounds, depends on the activity of lysosomal acidic sphingomyelinase (aSMase), $\mathrm{Zn}^{2+}$-independent, one of the enzymes participating in intracellular ceramide generation. Another important pathway of intracellular formation of ceramide is de novo synthesis with participation of ceramide synthase (CerS). The aim of this research is to assess the chemopreventive activity of FPh and $1 \mathrm{~b}$ and $3 \mathrm{f}$ compounds after irreversible CerS blockade.

\footnotetext{
${ }^{1}$ Katedra Podstaw Nauk Medycznych

${ }^{2}$ Katedra Chemii Leków

${ }^{3}$ SKN przy Katedrze Podstaw Nauk Medycznych

Uniwersytet Medyczny im. Piastów Śląskich we Wrocławiu
} 
Material and methods. Chemopreventive activity of the tested compounds (10 $\mu \mathrm{M}, 2 \mathrm{~h})$ was evaluated in human lymphocyte cultures, genotoxically damaged by benzo[a]pyrene (+B[a]P; 7,5 $\mu \mathrm{M}, 48 \mathrm{~h}$ ) and preincubated with a selective inhibitor CerS - fumonisin $\mathrm{B}_{1}\left(+\mathrm{FB}_{1} ; 20 \mu \mathrm{M}, 1,5 \mathrm{~h}\right)$ and inspected with fluorescence microscopy, as well as with spectrophotometric and spectrofluorimetric methods. Student's $t$-test was used for testing the statistical significance of the results.

Results. It was established that in the presence of the CerS inhibitor $\left(+\mathrm{B}[\mathrm{a}] \mathrm{P} ;+\mathrm{FB} \mathrm{B}_{1}\right)$ the effects of $1 \mathrm{~b}$ and $3 \mathrm{f}$ analogues on apoptotic cell frequency in lymphocyte cultures and on accumulation of rhodamine 123 (Rod-123), were significantly $(\mathrm{p}<0.05)$ decreased when compared to the cultures carried out in the absence of the CerS inhibitor $(+B[a] P$; $\left.-\mathrm{FB}_{1}\right)$. Whereas in the case of the parent compound: the FPh, the presence of the inhibitor did not influence on FPh chemopreventive activity.

Conclusions. The proapoptotic and chemosensitizing effects of $1 \mathrm{~b}$ and $3 \mathrm{f}$ compounds were determined in major part by CerS activation. Also the chemopreventive activity of the parent compound: the FPh, was independent of the cer de novo synthesis pathway conducted by CerS.

NOWOTWORY Journal of Oncology 2014; 64, 1: 7-15

Słowa kluczowe: apoptoza, ceramid, flufenazyna i jej analogi, glikoproteina P, syntetaza ceramidowa

Key words: apoptosis, ceramide, fluphenazine and its analogues, P-glycoprotein, synthase ceramide

\section{Wstęp}

W związku z systematycznie rosnącą liczbą przypadków nowotworów u ludzi pilną potrzebą jest opracowanie strategii obniżenia współczynnika zapadalności na chorobę nowotworową i opracowania zasad poprawy efektywności leczenia farmakologicznego różnego typu nowotworów [1-4].

Od lat 40. ubiegłego wieku chemioterapia stanowi podstawową metodę leczenia większości nowotworów [1]. Farmakoterapia cytostatyczna zazwyczaj wiąże się z ryzykiem wystąpienia u pacjentów wielu działań ubocznych, m.in.: efektu kardio-, mielo- i neurotoksycznego, zaburzeń ze strony przewodu pokarmowego, płuc, wątroby, nerek itp., które za względu na czas ich pojawienia sie podzielono na powikłania natychmiastowe, wczesne, opóźnione i późne [4-7]. Ponadto każda terapia lekami cytostatycznymi może być potencjalnie wtórnie karcenogenna [7, 8]. Istotnym ograniczeniem skuteczności chemioterapii jest także wielolekowa oporność (MDR - multidrug resistance) komórek nowotworowych na cytostatyki [9]. Wykazano, że zasadniczą rolę w indukowaniu zjawiska MDR odgrywa glikoproteina $P$ (P-gp — P-glycoprotein) — błonowe białko transportujące $z$ nadrodziny $A B C$ (ATP-binding cassette). Obecnie wiadomo, że P-gp, posiadająca aktywność ATP-azową, obniża wewnątrzkomórkowe gromadzenie leków cytostatycznych, będących substratami dla tego białka-transportera w komórkach nieprawidłowych — nowotworowych i/lub uszkodzonych genotoksycznie [1, 9-11].

W celu przeciwdziałania rozwojowi nowotworów, zmniejszenia skutków niepożądanych związanych z podawaniem cytostatyków i poprawy ostatecznych efektów chemioterapii stworzono strategię postępowania chemoprewencyjnego [12]. Aktualnie chemoprewencja nowo- tworów stała się elementem modelu terapii polecanego w onkologii, złożonego z wielu podstawowych zasad współczesnego leczenia nowotworów, zwanego całkowitą opieką (total care) [4].

Według kluczowych założeń sformułowanych przez Michaela Sporna w 1976 r., w chemoprewencji nowotworów, tzw. chemoprewencji wczesnej (pierwotnej), powinny znaleźć zastosowanie naturalne lub syntetyczne substancje chemiczne zapobiegające, spowalniające, a nawet odwracające progresję zmian nowotworowych w każdym stadium ich zaawansowania [13, 14]. Późniejsze modyfikacje definicji rozszerzyły pojęcie chemoprewencji o koncepcję chemoprewencji późnej (wtórnej), która ma polegać na zwiększeniu wrażliwości komórek nowotworowych i/lub uszkodzonych genotoksycznie na cytostatyki [14]. Naturalne lub syntetyczne związki chemiczne o potencjalnym wykorzystaniu w chemoprewencji późnej charakteryzują się zdolnością do nasilania odpowiedzi komórek nieprawidłowych na leki cytostatyczne, i nazwano je związkami chemouwrażliwiającymi (chemosensytyzującymi) [15]. Zasugerowano, że optymalne leki chemoprewencyjne/przeciwnowotorowe, stosowane razem z cytostatykami w terapii adiuwantowej nowotworów, powinny być inhibitorami funkcji transportowej P-gp, selektywnie wzbudzać apoptozę oraz zwiększać endogenną pulę proapoptotycznego ceramidu (cer) w komórkach nowotworowych i/lub uszkodzonych genotoksycznie [16-18].

Z danych z piśmiennictwa wynika, że kryteria dobrych preparatów chemoprewencyjnych spełniają pochodne fenotiazyny, dotąd stosowane w farmakologii jako leki neuroleptyczne; $w$ tej grupie są piperazynowe, typowe fenotiazyny - flufenazyna (FPh) i jej nowo syntezowane analogi, związki 1b i 3f [19-21]. Wyniki wcześniejszych badań 


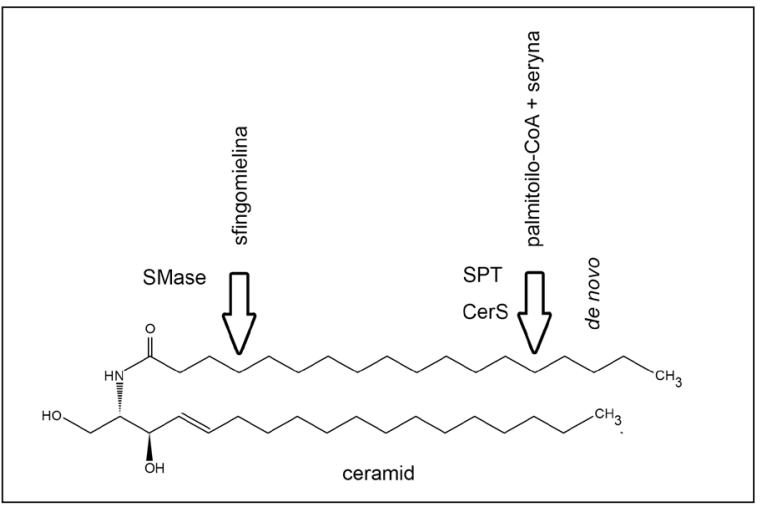

Rycina 1. Podstawowe szlaki tworzenia endogennego ceramidu. SMase - sfingomielinaza; CerS — syntetaza ceramidowa; SPT - transferaza seryna - palmitoilo-CoA

własnych w hodowlach limfocytów ludzkich uszkodzonych genotoksycznie przez wzorcowy premutagen — benzo[a] piren $(\mathrm{B}[a] \mathrm{P})$ - pokazały, że FPh i jej analogi: $1 \mathrm{~b}$ i $3 f$ są inhibitorami funkcji transportowej P-gp, a ich efekty: proapoptotyczny i chemouwrażliwiający w większym stopniu zależą od aktywacji lizosomalnej sfingomielinazy kwaśnej (aSMase), niezależnej od $\mathrm{Zn}^{2+}$, niż błonowej sfingomielinazy obojętnej (nSMase), zależnej od $\mathrm{Mg}^{2+}$ — głównych enzymów uczestniczących w powstawaniu wewnątrzkomórkowego cer [22-25].

Stwierdzono, że większość proapoptotycznego ceramidu (cer) jest generowana w komórce w następstwie hydrolizy sfingomieliny przez nSMase, zależną od $\mathrm{Mg}^{+2}$, i aSMase, niezależną od $\mathrm{Zn}^{+2}$. Innym ważnym szlakiem tworzenia endogennego cer uznano także syntezę de novo z udziałem transferazy seryna - plamitoilo-CoA (SPT) i syntetazy ceramidowej (CerS) [25-27].

Główne szlaki powstawania cer w komórce pokazano na rycinie 1.

\section{Cel pracy}

Celem pracy była ocena aktywności chemoprewencyjnej — proapoptotycznej i chemouwrażliwiającej - FPh i jej analogów: związków 1b i 3 f po nieodwracalnym zablokowaniu CerS.

\section{Materiał i metody Odczynniki chemiczne}

SIGMA-ALDRICH (St. Louis, MO, USA): Apo AF/PI Apoptosis Detection Kit, Caspase 3 Assay Kit, Colorimetric, fumonizyna $\mathrm{B}_{1}\left(\mathrm{FB}_{1}\right.$ ), rodamina 123 (Rod-123); GIBCO (Gaithesburg, MD, USA): Fitohemaglutynina typu M (PHA-M), Płyn Eagle'a (MEM), Surowica cielęca płodowa (FCS); Bio-Red Medical Diagnostics (Dreieich, Germany): Lymphoflot; SERVA (Heidelberg, Niemcy): Błękit trypanu; PAM „AQUA-MEDICA" (Łódź, Polska): Odczynnik Türka; Fluka (Buchs, Szwajcaria):
Benzo[a]piren (B[a]P); lliTD (Wrocław, Polska): PBS zbuforowany roztwór soli fizjologicznej; Polfa (Jelenia Góra, Polska): Dichlorowodorek flufenazyny (FPh).

Budowę chemiczną FPh i jej analogów 1b i 3f, jak również ich podstawowe parametry fizykochemiczne — masę cząsteczkową (M. cz.) i współczynnik podziału olej: woda (współczynnik lipofilności, LogP) zawarto w tabeli I.

Informacje o syntezie chemicznej analogów FPh można uzyskać na życzenie (wieslaw.malinka@umed.wroc.pl).

\section{Preparatyka limfocytów z krwi żylnej}

Krew żylną (20 ml) pobierano od zdrowych, niepalących ochotników płci męskiej w wieku 20-26 lat na antykoagulant - $10 \%$ r-r EDTA. Limfocyty izolowano techniką wirowania w gradiencie gęstości - Lymphoflot (Bio-Red Medical Diagnostics; Dreieich, Germany) przez 20 min [28]. Uzyskane limfocyty, po oddzieleniu osocza, erytrocytów i innych komórek jednojądrzastych, płukano czterokrotnie w MEM, a następnie zawieszano $w$ kompletnym środowisku hodowlanym - MEM $_{\text {komp. }}$ o składzie: MEM, 10\% FCS, gentamycyna $(25 \mu \mathrm{g} / \mathrm{ml})$ i PHA-M (2\% v/v). Liczebność wyizolowanych komórek modelowych oceniano na siatce hematologicznej Bürkera za pomocą odczynnika Türka, użytego w stosunku 1:10. Natomiast żywotność limfocytów określano po ich wybarwieniu 0,4\% roztworem błękitu trypanu w PBS w stosunku 1:1. Na wykonanie badań własnych otrzymano zgodę Komisji Bioetycznej przy Uniwersytecie Medycznym we Wrocławiu (Nr KB-461/2008).

\section{Hodowle limfocytów}

Wyizolowane limfocyty, umieszczone w $\mathrm{MEM}_{\text {komp }}$ i podzielone na próby, inkubowano $w$ temperaturze $37^{\circ} \mathrm{C}$, w atmosferze $5 \% \mathrm{CO}_{2}$ o $100 \%$ wilgotności przez 2 dni (48 godz.) z B[a]P (+B[a]P; 7,5 $\mu \mathrm{M})$. Pod koniec hodowli do komórek modelowych dodawano selektywny, nieodwracalny inhibitor CerS - FB1 (+FB1; $20 \mu \mathrm{M}, 1,5 \mathrm{godz} .37^{\circ} \mathrm{C}$ ), a następnie, po wymianie supernatantu, wodne roztwory badanych związków (10 $\mu \mathrm{M}, 2$ godz., $\left.37^{\circ} \mathrm{C}\right)$. Stężenia i czasy inkubacji limfocytów ze związkami chemicznymi użytymi w obserwacjach in vitro ustalono eksperymentalnie. W wykonanych badaniach kontrole stanowiły hodowle limfocytów uszkodzone przez $\mathrm{B}[\mathrm{a}] \mathrm{P}$, prowadzone w obecności FB1 (+B[a]P; +FB1) lub bez FB1 (+B[a]P; -FB1) i zawsze bez testowanych Pht. Wszystkie doświadczenia in vitro powtórzono pięciokrotnie $(n=5)$.

\section{Test identyfikacji apoptozy — mikroskopia fluorescencyjna}

Do oceny wizualnej limfocytów z cechami apoptozy w badanych hodowlach komórkowych zastosowano technikę z użyciem mikroskopu fluorescencyjnego i zestawu Apo AF/PI Apoptosis Detection Kit (SIGMA-ALDRICH; St. Louis, MO, USA), szczegółowo opisaną w piśmiennictwie [19]. Po analizie przygotowanych preparatów naszkiełko- 
Tabela I. Charakterystyka chemiczna FPh i jej analogów

\begin{tabular}{|l|l|l|}
\hline Badane związki & LogP \\
\hline
\end{tabular}

wych (komórki żywe - bezbarwne; komórki w apoptozie — zielone lub zielone z pomarańczową obwódką; komórki martwe - pomarańczowe) i oszacowaniu odsetka komórek apoptotycznych w poszczególnych próbach obliczono współczynniki apoptozy $\left(\mathrm{W}_{\mathrm{apo}}\right) \mathrm{wg}$ wzoru:

\footnotetext{
\% komórek $w$ apoptozie $w$ hodowlach $+\mathrm{B}[a] \mathrm{P} ;+\mathrm{FB}_{1}$ z badanymi związkami/\% komórek w apoptozie w kontroli $+\mathrm{B}[a] \mathrm{P} ;+\mathrm{FB}_{1}$

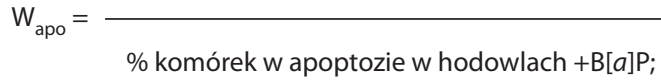

$-\mathrm{FB}_{1} \mathrm{z}$ badanymi związkami/\% komórek $w$ apoptozie $\mathrm{w}$ kontroli $+\mathrm{B}[a] \mathrm{P} ;-\mathrm{FB}_{1}$
}

\section{Test oceny aktywności kaspazy-3 - metoda kolorymetryczna}

Aktywność wykonawczej kaspazy-3 (Casp-3) zmierzono techniką kolorymetryczną z użyciem zestawu Caspase 3 Assay Kit, Colorimetric (SIGMA-ALDRICH; St. Louis, MO, USA), za pomocą aparatu Victor ${ }^{2}$ [19]. Casp-3 hydrolitycznie rozkłada syntetyczny substrat - Ac-DEVD-pNa (acetylo-Asp-Glu-Val-Asp-p-nitroanilina), prowadząc do uwolnienia żółto zabarwionej p-nitroaniliny ( $p-N A$ ), cechującej się wysoką absorbancją przy długości fali $\lambda=405 \mathrm{~nm}$. Ustalono eksperymentalnie, że ilość uwolnionej $\mathrm{p}$-Na jest wprost proporcjonalna do aktywności Casp-3 w badanych hodowlach.

Wyniki otrzymano w umownych jednostkach absorbancji (AAU; absorbance arbitrary unit) enzymatycznie uwolnionej p-NA, na podstawie których obliczono współczynniki absorbancji $\left(\mathrm{W}_{\mathrm{AAU}}\right)$ wg wzoru:

absorbancja p-NA w hodowlach $+\mathrm{B}[a] \mathrm{P} ;+\mathrm{FB}_{1} \mathrm{z}$ badanymi związkami [AAU]/absorbancja p-NA w kontroli $+\mathrm{B}[a] \mathrm{P} ;+\mathrm{FB}_{1}[\mathrm{AAU}]$ $\mathrm{W}_{\mathrm{AAU}}=$

absorbancja p-NA w hodowlach $+\mathrm{B}[a] \mathrm{P} ;-\mathrm{FB}_{1} \mathrm{z}$ badanymi związkami [AAU]/absorbancja p-NA w kontroli $+\mathrm{B}[a] \mathrm{P} ;-\mathrm{FB}_{1}[\mathrm{AAU}]$

\section{Test akumulacji Rod-123 - metoda spektrofluorymetryczna}

Pomiary spektrofluorymetryczne przeprowadzono za pomocą aparatu Victor ${ }^{2}$, mierząc gromadzenie Rod$123\left(5 \mu \mathrm{M}, 1 \mathrm{godz} .3^{\circ} \mathrm{C}\right) \mathrm{w}$ badanych hodowlach limfocytów. Rod-123 jest nietoksycznym dla komórek fluorochromem o $\lambda_{\text {wzbudzenia }}=485 \mathrm{~nm} \mathrm{i} \lambda_{\text {emisji }}=530 \mathrm{~nm}$. Stwierdzono, że $w$ testach in vitro wykorzystywanych do oceny aktywności P-gp, Rod-123 może zastąpić wszystkie substraty tego białka transportującego [19].

Wyniki otrzymano w umownych jednostkach fluorescencji (FAU - fluorescence arbitrary unit) wewnątrzko- 
mórkowo zgromadzonej Rod-123, na podstawie których obliczono współczynniki fluorescencji $\left(\mathrm{W}_{\mathrm{FAU}}\right) \mathrm{wg}$ wzoru:

fluorescencja Rod-123 w hodowlach $+\mathrm{B}[a] \mathrm{P}_{;}+\mathrm{FB}_{1}$ z badanymi związkami [FAU]/fluorescencja Rod-123 w kontroli $+\mathrm{B}[a] \mathrm{P} ;+\mathrm{FB}_{1}[\mathrm{FAU}]$ $\mathrm{W}_{\mathrm{FAU}}=$

fluorescencja Rod-123 w hodowlach $+\mathrm{B}[a] \mathrm{P} ;-\mathrm{FB}_{1}$ z badanymi związkami [FAU]/fluorescencja Rod-123 w kontroli $+\mathrm{B}[a] \mathrm{P} ;-\mathrm{FB}_{1}[\mathrm{FAU}]$

\section{Analiza statystyczna}

Obliczenia statystyczne wykonano za pomocą programów komputerowych: StatSoft, Inc.(2012 r.) Statistica v. 10.1 oraz Microsoft $^{\oplus}$ Excel 2003. Do oceny danych uzyskanych w przeprowadzonych testach in vitro zastosowano podstawowe statystyki opisowe: średnią arytmetyczną z uwzględnieniem odchylenia standardowego ( $\bar{x} \pm$ s.d.), medianę (Med.), rozstęp ( $R=$ wartość maksymalna - wartość minimalna) i współczynnik zmienności $(\gamma=$ s.d./ $\bar{x})$. Istotność statystyczną różnic między średnimi arytmetycznymi oceniono testem $t$-Studenta. Za istotne statystycznie przyjęto $p<0,05$. Wyniki analizy statystycznej zaprezentowano $w$ tabelach oraz $w$ treści opracowania.

\section{Wyniki i ich omówienie}

Chemoprewencyjny: proapoptotyczny i chemouwrażliwiający efekt FPh oraz jej analogów - 1b i 3f - oceniono w hodowlach limfocytów ludzkich w układzie modelowym, rekomendowanym w piśmiennictwie do badań aktywności chemoprewencyjnej [19]. Limfocyty inkubowano ze standardowym premutagenem $-\mathrm{B}[a] \mathrm{P}\left(7,5 \mu \mathrm{M}, 48 \operatorname{godz} ., 37^{\circ} \mathrm{C}\right)$, w celu ich upodobnienia do komórek nowotworowych (wywołania uszkodzeń genotoksycznych) oraz zwiększenia ekspresji P-gp [19]. Do oceny działania chemoprewencyjnego badanych związków użyto trzy testy biologiczne in vitro: $1^{\circ}$ test identyfikacji apoptozy w mikroskopie fluorescencyjnym, $2^{\circ}$ test oceny aktywności Casp-3 metodą kolorymetryczną i $3^{\circ}$ test oceny akumulacji Rod-123 metodą spektrofluorymetryczną [19].

W obserwacjach własnych zastosowano mykotoksynę - $\mathrm{FB}_{1}$. Wykazano, że $\mathrm{FB}_{1}$ jest selektywnym, nieodwracalnym inhibitorem CerS i w zależności od stężenia zmniejsza wewnątrzkomórkową pulę cer [29, 30]. Do badań in vitro w hodowlach limfocytów $(+\mathrm{B}[a] \mathrm{P})$ wybrano $\mathrm{FB}_{1}$ w stężeniu $20 \mu \mathrm{M}$ i, często polecany w piśmiennictwie, czas inkubacji komórek z inhibitorem - 1,5 godz. [dane niepokazane]. Natomiast FPh oraz analogi $1 \mathrm{~b}$ i $3 \mathrm{f}$ zastosowano w stężeniu $10 \mu \mathrm{M}$ ( 2 godz., $37^{\circ} \mathrm{C}$ ), maksymalnym, które nie wpływało cytotoksycznie w przygotowanym układzie doświadczalnym i dawało powtarzalne rezultaty w kolejnych eksperymentach [19].

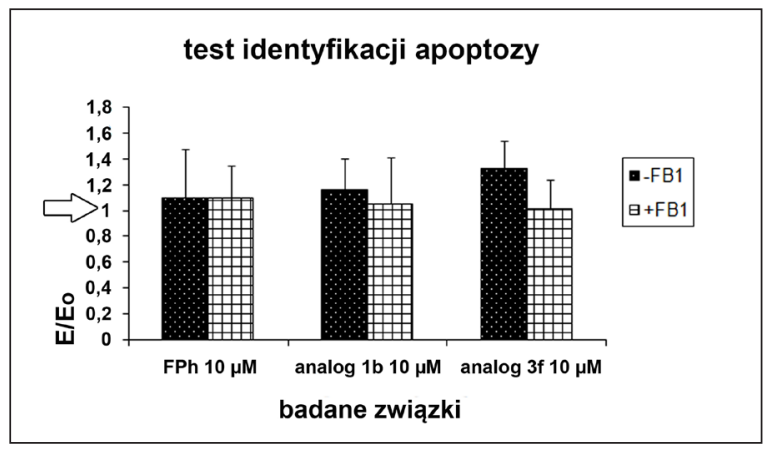

Rycina 2. Wpływ FPh oraz analogów $1 \mathrm{~b}$ i $3 \mathrm{f}$ w stężeniu $10 \mu \mathrm{M}$ $\left(2\right.$ godz., $\left.37^{\circ} \mathrm{C}\right)$ na odsetek komórek apoptotycznych w hodowlach limfocytów uszkodzonych genotoksycznie (+B[a]P; 7,5 $\mu \mathrm{M}, 48$ godz., $\left.37^{\circ} \mathrm{C}\right)$, niepreinkubowanych z $\mathrm{FB}_{1}\left(-\mathrm{FB}_{1}\right)$ i preinkubowanych z $\mathrm{FB}_{1}$ (+FB $; 20 \mu \mathrm{M}, 1,5 \mathrm{godz} ., 37^{\circ} \mathrm{C}$ ). Odsetek komórek apoptotycznych w każdej badanej próbie (E) porównano z odsetkiem komórek apoptotycznych w odpowiednich hodowlach kontrolnych $\left(\mathrm{E}_{\mathrm{o}}\right)$ i wyrażono jako $E / E_{o} ; n=5$. Na rycinie poziom kontroli wskazano strzałką. Test identyfikacji apoptozy — metoda fluorescencyjna

\section{Ocena mikroskopowa częstości apoptozy w hodowlach limfocytów uszkodzonych genotoksycznie po zablokowaniu CerS}

Test identyfikacji apoptozy w mikroskopie fluorescencyjnym polega na wizualnej ocenie morfologii komórek po ich wybarwieniu mieszaniną fluorochromów - aneksyną V-FITC i jodkiem propydyny. Na preparatach naszkiełkowych, przygotowanych z poszczególnych prób, zliczano limfocyty z cechami apoptozy (zabarwione na zielono lub zielono-pomarańczowo). Odsetek limfocytów apoptotycznych w hodowlach prowadzonych bez $\mathrm{FB}_{1}\left(-\mathrm{FB}_{1}\right)$ lub z FB $\mathrm{FB}_{1}\left(+\mathrm{FB}_{1}\right)$ oraz inkubowanych z badanymi związkami (E) odniesiono do odsetka limfocytów apoptotycznych w odpowiednich kontrolach $\left(E_{0}\right)$ i przedstawiono jako $E / E_{0}$ w histogramach na rycinie 2 .

Podstawowe statystyki opisowe wyników otrzymanych $w$ teście identyfikacji apoptozy metodą fluorescencyjną zamieszczono w tabeli IIA.

Istotność statystyczną danych otrzymanych w teście identyfikacji apoptozy metodą fluorescencyjną wyliczono w teście-t, a wyniki analizy statystycznej zamieszczono w tabeli IIB.

Jak widać na rycinie 2 i w tabeli IIA, w hodowlach limfocytów uszkodzonych genotoksycznie (+B[a]P) niepreinkubowanych z FB $\mathrm{F}_{1}\left(-\mathrm{FB}_{1}\right)$ wykazano, że zarówno macierzysta FPh, jak i analogi 1b i $3 f$ prowadziły do wzrostu odsetka komórek z cechami apoptozy w porównaniu z kontrolą (+B $[a] \mathrm{P}$; $-\mathrm{FB}_{1}$ ). Natomiast po dodaniu do medium hodowlanego $\mathrm{FB}_{1}\left(+\mathrm{FB}_{1}\right)$ odsetek komórek z cechami apoptozy w obecności badanych analogów okazał się niższy, a w przypadku $\mathrm{FPh}$ - podobny jak w hodowlach bez $\mathrm{FB}_{1}\left(+\mathrm{B}[a] \mathrm{P} ;-\mathrm{FB}_{1}\right)$. Obniżenie częstości apoptozy pod wpływem analogów 1b 
Tabela IIA. Odsetek komórek modelowych z cechami apoptozy w badanych hodowlach

\begin{tabular}{|c|c|c|c|c|c|c|c|c|}
\hline \multicolumn{9}{|c|}{ Test identyfikacji apoptozy } \\
\hline & \multicolumn{4}{|c|}{$-\mathrm{FB}_{1}$} & \multicolumn{4}{|c|}{$+\mathrm{FB}_{1}$} \\
\hline & $\bar{\chi} \pm$ s.d. $\mathrm{n}=5[\%]$ & Med. & $R$ & $Y$ & $\bar{\chi} \pm$ s.d. $n=5[\%]$ & Med. & $R$ & $\gamma$ \\
\hline $\mathrm{FPh} 10 \mu \mathrm{M}$ & $47,64 \pm 9,49$ & 47,64 & 21,2 & 0,199 & $50,02 \pm 8,44$ & 53 & 19,9 & 0,169 \\
\hline Analog $1 \mathrm{~b} 10 \mu \mathrm{M}$ & $51,43 \pm 4,14$ & 51,43 & 9,2 & 0,081 & $42,26 \pm 7,33$ & 43,1 & 17 & 0,173 \\
\hline Analog $3 f 10 \mu \mathrm{M}$ & $59,3 \pm 7,61$ & 57,9 & 18 & 0,128 & $42,74 \pm 9,65$ & 39 & 25 & 0,226 \\
\hline Kontrola +B[a]P & $45,58 \pm 10,74$ & 45,58 & 20,7 & 0,236 & $43,48 \pm 13,13$ & 40,9 & 33 & 0,302 \\
\hline
\end{tabular}

ұ s.d. — średnia arytmetyczna \pm odchylenie standardowe; Med. — mediana; $R$ — rozstęp; $Y$ — współczynnik zmienności

Tabela IIB. Test- $t$ w ocenie istotności statystycznej wyników otrzymanych w teście identyfikacji apoptozy

1. Ocena istotności różnic odsetka komórek modelowych z cechami apoptozy w hodowlach z badanymi związkami, niepreinkubowanych z FB ${ }_{1}\left(-F_{1}\right.$ ) lub preinkubowanych z $\mathrm{FB}_{1}\left(+\mathrm{FB}_{1}\right)$ i w odpowiednich kontrolach

\begin{tabular}{|c|c|c|c|c|c|c|c|c|}
\hline \multirow[t]{3}{*}{ Test- $t$ (p) } & \multicolumn{4}{|c|}{$-\mathrm{FB}_{1}$} & \multicolumn{4}{|c|}{$+\mathrm{FB}_{1}$} \\
\hline & $\begin{array}{c}\text { Kontrola } \\
+\mathrm{B}[a] \mathrm{P}\end{array}$ & $\begin{array}{c}\mathrm{FPh} \\
10 \mu \mathrm{M}\end{array}$ & $\begin{array}{c}\text { Analog } 1 \mathrm{~b} \\
10 \mu \mathrm{M}\end{array}$ & $\begin{array}{c}\text { Analog } 3 f \\
10 \mu \mathrm{M}\end{array}$ & $\begin{array}{c}\text { Kontrola } \\
+\mathrm{B}[a] \mathrm{P}\end{array}$ & $\begin{array}{c}\mathrm{FPh} \\
10 \mu \mathrm{M}\end{array}$ & $\begin{array}{c}\text { Analog } 1 \mathrm{~b} \\
10 \mu \mathrm{M}\end{array}$ & $\begin{array}{c}\text { Analog } 3 f \\
10 \mu \mathrm{M}\end{array}$ \\
\hline & - & 0,$77 ; N S^{*}$ & 0,$2 ; N S^{*}$ & 0,009 & - & 0,$262 ; N S$ & 0,$893 ; N S$ & 0,$865 ; N S$ \\
\hline
\end{tabular}

2. Ocena istotności różnic odsetka komórek modelowych z cechami apoptozy w hodowlach bez FB $_{1}\left(-\mathrm{FB}_{1}\right)$ lub z FB F $_{1}\left(+\mathrm{FB}_{1}\right)$ i z poszczególnymi badanymi związkami

\begin{tabular}{lccc}
\hline & \multicolumn{3}{c}{ Test- $t(\mathrm{p})$} \\
\cline { 2 - 4 } & $\begin{array}{c}\mathrm{FPh} \\
10 \mu \mathrm{M}\end{array}$ & $\begin{array}{c}\text { Analog } 1 \mathrm{~b} \\
10 \mu \mathrm{M}\end{array}$ & $\begin{array}{c}\text { Analog } 3 f \\
10 \mu \mathrm{M}\end{array}$ \\
\hline$-\mathrm{FB}_{1}$ & 0,$677 ; N S$ & 0,044 & 0,045 \\
$+\mathrm{FB}_{1}$ & & & \\
\hline
\end{tabular}

${ }^{*} N S$ - nieistotne statystycznie

i 3 f w hodowlach limfocytów $(+B[a] \mathrm{P})$ preinkubowanych z inhibitorem CerS $\left(+\mathrm{FB}_{1}\right)$ w odniesieniu do hodowli limfocytów $(+\mathrm{B}[\mathrm{a}] \mathrm{P})$ niepreinkubowanych z inhibitorem CerS $\left(-\mathrm{FB}_{1}\right)$ było istotne statystycznie $(p<0,05)$, co może sugerować udział szlaku syntezy cer de novo z aktywacją CerS w działaniu proapoptotycznym badanych analogów (tab. IIB).

\section{Ocena kolorymetryczna aktywności Casp-3 w hodowlach limfocytów uszkodzonych genotoksycznie po zablokowaniu CerS}

Udowodniono, że Casp-3 jest główną kaspazą wykonawczą większości szlaków apoptozy, również apoptozy indukowanej cer, a wzrost jej aktywności uznano za znacznik postępu śmierci apoptotycznej [31-33]. Dlatego w badaniach własnych zmierzono aktywność Casp-3, równolegle do mikroskopowej oceny częstości apoptozy w hodowlach limfocytów (+B[a]P).

Aktywność wykonawczej Casp-3/absorbancję uwolnionej p-NA [AAU] w hodowlach limfocytów prowadzonych bez $\mathrm{FB}_{1}\left(-\mathrm{FB}_{1}\right)$ lub $z \mathrm{FB}_{1}\left(+\mathrm{FB}_{1}\right)$ oraz inkubowanych $\mathrm{z}$ badanymi związkami(E) odniesionodoaktywności wykonawczejCasp-3/ /absorbancji uwolnionej p-NA [AAU] w odpowiednich kontrolach $\left(E_{0}\right)$ i przedstawiono jako $E_{/} E_{o}$ w histogramach na rycinie 3 .

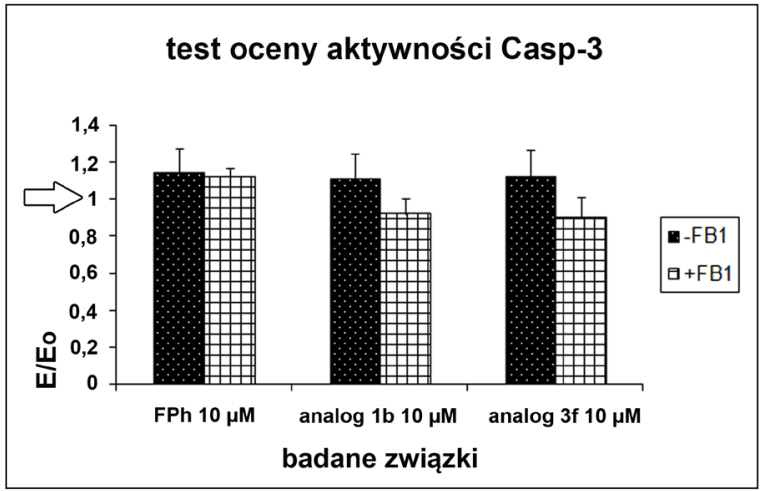

Rycina 3. Wpływ FPh oraz analogów 1b i 3f w stężeniu $10 \mu \mathrm{M}$ $\left(2\right.$ godz., $37^{\circ} \mathrm{C}$ ) na aktywność wykonawczej Casp-3 w hodowlach limfocytów uszkodzonych genotoksycznie (+B[a]P; 7,5 $\mu \mathrm{M}, 48$ godz., $\left.37^{\circ} \mathrm{C}\right)$, niepreinkubowanych z $\mathrm{FB}_{1}\left(-\mathrm{FB}_{1}\right)$ i preinkubowanych z FB $\left(+\mathrm{FB}_{1} ; 20 \mu \mathrm{M}, 1,5 \mathrm{godz} .3^{\circ} \mathrm{C}\right)$. Aktywność Casp-3/absorbancję uwolnionej $\mathrm{p}-\mathrm{Na}[\mathrm{AAU}] \mathrm{w}$ każdej badanej próbie (E) porównano z aktywnością Casp-3/absorbancją uwolnionej p-Na [AAU] w odpowiednich hodowlach kontrolnych $\left(E_{o}\right)$ i wyrażono jako $E / E_{o}$; $\mathrm{n}=5$. Na rycinie poziom kontroli wskazano strzałką. Test oceny aktywności Casp-3 - metoda kolorymetryczna

Podstawowe statystyki opisowe wyników otrzymanych w teście oceny aktywności Casp-3 metodą kolorymetryczną zamieszczono w tabeli IIIA. 
Tabela IIIA. Aktywność Casp-3/absorbancja p-NA w badanych hodowlach

\begin{tabular}{|c|c|c|c|c|c|c|c|c|}
\hline \multicolumn{9}{|c|}{ Test oceny aktywności Casp-3 } \\
\hline & \multicolumn{4}{|c|}{$-\mathrm{FB}_{1}$} & \multicolumn{4}{|c|}{$+\mathrm{FB}_{1}$} \\
\hline & $\begin{array}{c}\bar{\chi} \pm \text { s.d. } n=5 \\
{[\mathrm{AAU}]}\end{array}$ & Med. & $R$ & $\gamma$ & $\begin{array}{c}\bar{\chi} \pm \text { s.d. } \mathrm{n}=5 \\
{[\mathrm{AAU}]}\end{array}$ & Med. & $R$ & $\gamma$ \\
\hline $\mathrm{FPh} 10 \mu \mathrm{M}$ & $0,059 \pm 0,002$ & 0,059 & 0,006 & 0,0404 & $0,069 \pm 0,011$ & 0,069 & 0,028 & 0,163 \\
\hline Analog $1 \mathrm{~b} 10 \mu \mathrm{M}$ & $0,057 \pm 0,003$ & 0,057 & 0,008 & 0,0541 & $0,057 \pm 0,01$ & 0,056 & 0,026 & 0,18 \\
\hline Analog $3 f 10 \mu \mathrm{M}$ & $0,058 \pm 0,005$ & 0,058 & 0,012 & 0,0814 & $0,056 \pm 0,014$ & 0,05 & 0,034 & 0,2563 \\
\hline Kontrola +B[a]P & $0,052 \pm 0,006$ & 0,05 & 0,014 & 0,1121 & $0,062 \pm 0,009$ & 0,059 & 0,022 & 0,1441 \\
\hline
\end{tabular}

AAU — umowne jednostki absorbancji p-NA; $\bar{\chi} \pm$ s.d. — średnia arytmetyczna \pm odchylenie standardowe; Med. — mediana; R — rozstęp; Y — współczynnik zmienności

Tabela IIIB. Test- $t$ w ocenie istotności statystycznej wyników otrzymanych w teście oceny aktywności Casp-3

1. Ocena istotności różnic absorbancji p-NA w hodowlach z badanymi związkami, niepreinkubowanych z FB $F_{1}\left(-\mathrm{FB}_{1}\right)$ lub preinkubowanych z FB ${ }_{1}\left(+\mathrm{FB}_{1}\right.$ ) i w odpowiednich kontrolach

\begin{tabular}{|c|c|c|c|c|c|c|c|c|}
\hline \multirow[t]{3}{*}{ Test- $t(p)$} & \multicolumn{4}{|c|}{$-\mathrm{FB}_{1}$} & \multicolumn{4}{|c|}{$+\mathrm{FB}_{1}$} \\
\hline & $\begin{array}{c}\text { Kontrola } \\
+\mathrm{B}[a] \mathrm{P}\end{array}$ & $\begin{array}{c}\mathrm{FPh} \\
10 \mu \mathrm{M}\end{array}$ & $\begin{array}{c}\text { Analog } 1 \mathrm{~b} \\
10 \mu \mathrm{M}\end{array}$ & $\begin{array}{c}\text { Analog } 3 f \\
10 \mu \mathrm{M}\end{array}$ & $\begin{array}{c}\text { Kontrola } \\
+\mathrm{B}[a] \mathrm{P}\end{array}$ & $\begin{array}{c}\mathrm{FPh} \\
10 \mu \mathrm{M}\end{array}$ & $\begin{array}{c}\text { Analog } 1 \mathrm{~b} \\
10 \mu \mathrm{M}\end{array}$ & $\begin{array}{c}\text { Analog } 3 f \\
10 \mu \mathrm{M}\end{array}$ \\
\hline & - & 0,$087 ; N S^{*}$ & 0,$184 ; N S^{*}$ & 0,$17 ; N S^{*}$ & - & 0,008 & 0,$095 ; N S$ & 0,$152 ; N S$ \\
\hline
\end{tabular}

2. Ocena istotności różnic absorbancji p-NA w hodowlach bez $\mathrm{FB}_{1}\left(-\mathrm{FB}_{1}\right)$ lub z FB $\mathrm{FB}_{1}\left(+\mathrm{FB}_{1}\right)$ i z poszczególnymi badanymi związkami

\begin{tabular}{lccc}
\hline & \multicolumn{3}{c}{ Test- $t(\mathrm{p})$} \\
\cline { 2 - 4 } & $\begin{array}{c}\mathrm{FPh} \\
10 \mu \mathrm{M}\end{array}$ & $\begin{array}{c}\text { Analog } 1 \mathrm{~b} \\
10 \mu \mathrm{M}\end{array}$ & $\begin{array}{c}\text { Analog } 3 f \\
10 \mu \mathrm{M}\end{array}$ \\
\hline$-\mathrm{FB}_{1}$ & 0,$141 ; N S$ & 0,$968 ; N S$ & 0,$828 ; N S$ \\
$+\mathrm{FB}_{1}$ & & & \\
\hline
\end{tabular}

${ }^{*} N S$ - nieistotne statystycznie

Istotność statystyczną danych otrzymanych w teście oceny aktywności Casp-3 metodą kolorymetryczną wyliczono w teście-t, a wyniki analizy statystycznej zamieszczono w tabeli IIIB.

Jak widać na rycinie 3 oraz z tabeli IIIA i z tabeli IIIB, po nieodwracalnym zablokowaniu CerS inkubacja hodowli limfocytów $\left(+\mathrm{B}[\mathrm{a}] \mathrm{P} ;+\mathrm{FB}_{1}\right) \mathrm{z}$ analogami $1 \mathrm{~b}$ i 3 f prowadziła do nieistotnego statystycznie ( $p>0,05)$ spadku aktywności Casp-3 w porównaniu z kontrolą $\left(+\mathrm{B}[a] \mathrm{P} ;+\mathrm{FB}_{1}\right)$; była także nieistotnie $(p>0,05)$ niższa niż w hodowlach $\left(+B[a] \mathrm{P} ;-\mathrm{FB}_{1}\right)$. Otrzymane wyniki wskazują zatem, że efekt proapoptotyczny analogów 1b i 3f, uwarunkowany aktywacją szlaku syntezy cer de novo i pobudzeniem CerS, prawdopodobnie nie zależy od stymulacji Casp-3. Natomiast w hodowlach limfocytów $(+\mathrm{B}[\mathrm{a}] \mathrm{P})$, po nieodwracalnym zablokowaniu CerS, w obecności FPh stwierdzono znamienny $(p<0,05)$ wzrost aktywności Casp-3 w stosunku do kontroli (+B[a]P; $+\mathrm{FB}_{1}$ ). Rezultaty te potwierdzają dane uzyskane w teście identyfikacji apoptozy w mikroskopie fluorescencyjnym o niezależności efektu proapoptotycznego FPh od szlaku syntezy cer de novo z udziałem Cers.

\section{Ocena spektrofluorymetryczna akumulacji Rod-123 w hodowlach limfocytów uszkodzonych genotoksycznie po zablokowaniu CerS}

Spektrofluorymetryczny test akumulacji Rod-123 służy do oceny czynności P-gp i zarazem właściwości chemouwrażliwiających związków o charakterze inhibitorów tego białka transportującego [19]. Akumulację Rod-123 [FAU] w hodowlach limfocytów prowadzonych bez $\mathrm{FB}_{1}\left(-\mathrm{FB}_{1}\right)$ lub z $\mathrm{FB}_{1}\left(+\mathrm{FB}_{1}\right)$ oraz inkubowanych z badanymi związkami (E) odniesiono do akumulacji Rod-123 [FAU] w odpowiednich kontrolach $\left(E_{o}\right)$ i przedstawiono jako $E / E_{o}$ w histogramach na rycinie 4.

Podstawowe statystyki opisowe wyników otrzymanych w teście akumulacji Rod-123 metodą spektrofluorymetryczną zamieszczono w tabeli IVA.

Istotność statystyczną danych otrzymanych w teście akumulacji Rod-123 metodą spektrofluorymetryczną wyliczono w teście-t, a wyniki analizy statystycznej zamieszczono $w$ tabeli IVB.

Jak widać na rycinie 4 oraz $z$ tabeli IVA i z tabeli IVB, inkubacja limfocytów (+B[a]P) z FB ${ }_{1}$, w przypadku analogów $1 \mathrm{~b}$ i 3f, prowadziła do istotnego statystycznie $(p<0,05)$ 


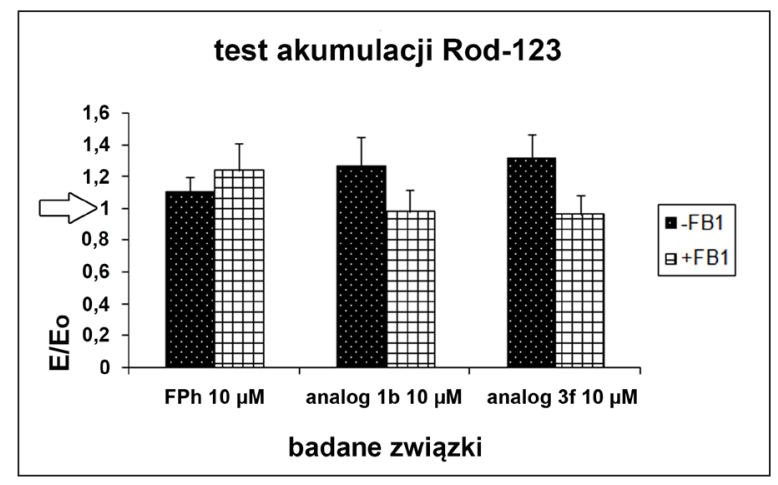

Rycina 4. Wpływ FPh oraz analogów 1b i 3f w stężeniu $10 \mu \mathrm{M}$ $\left(2\right.$ godz., $\left.37^{\circ} \mathrm{C}\right)$ na intensywność akumulacji Rod- 123 w hodowlach limfocytów uszkodzonych genotoksycznie (+B[a]P; 7,5 $\mu \mathrm{M}, 48$ godz., $\left.37^{\circ} \mathrm{C}\right)$, niepreinkubowanych z $\mathrm{FB}_{1}\left(-\mathrm{FB}_{1}\right)$ i preinkubowanych z FB $\left(+\mathrm{FB}_{1} ; 20 \mu \mathrm{M}, 1,5 \mathrm{godz} .3^{\circ} \mathrm{C}\right)$. Intensywność akumulacji Rod-123 [FAU] w każdej badanej próbie (E) porównano z intensywnością akumulacji Rod-123 [FAU] w odpowiednich hodowlach kontrolnych $\left(E_{o}\right)$ i wyrażono jako $E / E_{o} ; n=5$. Na rycinie poziom kontroli wskazano strzałką. Test oceny akumulacji Rod-123 — metoda spektrofluorymetryczna

spadku gromadzenia Rod-123 w porównaniu z hodowlami prowadzonymi bez $\mathrm{FB}_{1}$ i zarazem gromadzenia Rod-123 na poziomie kontroli $\left(+\mathrm{B}[a] \mathrm{P} ;+\mathrm{FB}_{1}\right)$. Otrzymane rezultaty pokazują, że obecność $F B_{1}$ w hodowlach $(+B[a] P)$ z analogami 1b i $3 f$ znacząco zmniejsza akumulację Rod-123. Sugeruje to, że zdolność badanych analogów do blokowania funkcji transportowej P-gp może być uwarunkowana stymulacją CerS.

Natomiast dla macierzystej FPh w hodowlach $(+\mathrm{B}[a] \mathrm{P})$ - po zablokowaniu CerS - stwierdzono znamienny $(p<0,05)$ wzrost gromadzenia Rod-123 w porównaniu z kontrolą ( $\left.+\mathrm{B}[a] \mathrm{P} ;+\mathrm{FB}_{1}\right)$ i zarazem nieistotny statystycznie ( $p>0,05$ ) wzrost gromadzenia Rod-123 w odniesieniu do wyników otrzymanych w hodowlach komórkowych $(+\mathrm{B}[a] \mathrm{P})$ bez $\mathrm{FB}_{1}\left(-\mathrm{FB}_{1}\right)$ (tab. IVB). Uzyskane dane wskazują, że zablokowanie CerS nasila aktywność FPh jako inhibitora P-gp. Niewykluczone zatem jest, że dezaktywacja szlaku de novo tworzenia cer w komórce pośrednio zwiększa efekt chemouwrażliwiający FPh z udziałem innych ścieżek powstawania i/lub metabolizmu cer lub na szlakach niezależnych od cer.

\section{Porównanie aktywności chemoprewencyjnej badanych zwiq̨zków}

W celu porównania działania chemoprewencyjnego - proapoptotycznego i chemouwrażliwiającego - FPh oraz jej analogów, 1b i 3f, jak również zestawienia danych dotyczących wpływu aktywnej CerS na ich efekt biologiczny, dla każdego badanego związku obliczono współczynniki: $\mathrm{W}_{\text {apo }}, \mathrm{W}_{\mathrm{AAU}}$ i $\mathrm{W}_{\mathrm{FAU}}$.

Współczynniki $\mathrm{W}_{\mathrm{apo}^{\prime}} \mathrm{W}_{\mathrm{AAU}} \mathrm{iW}_{\mathrm{FAU}}$ dla FPh oraz analogów $1 \mathrm{~b}$ i $3 f$ zamieszczono $w$ tabeli $V$.

Tabela IVA. Akumulacja Rod-123 w badanych hodowlach

\begin{tabular}{|c|c|c|c|c|c|c|c|c|}
\hline \multicolumn{9}{|c|}{ Test oceny intensywności akumulacji Rod-123 } \\
\hline & \multicolumn{4}{|c|}{$-\mathrm{FB}_{1}$} & \multicolumn{4}{|c|}{$+\mathrm{FB}_{1}$} \\
\hline & $\begin{array}{c}\bar{\chi} \pm \text { s.d. } \mathrm{n}=5 \\
{[\mathrm{FAU}]}\end{array}$ & Med. & $R$ & $\gamma$ & $\begin{array}{c}\bar{\chi} \pm \text { s.d. } \mathrm{n}=5 \\
{[\mathrm{FAU}]}\end{array}$ & Med. & $R$ & $\gamma$ \\
\hline $\mathrm{FPh} 10 \mu \mathrm{M}$ & $85 \pm 6,26$ & 86 & 16 & 0,074 & $92 \pm 12,10$ & 94 & 29 & 0,132 \\
\hline Analog $1 \mathrm{~b} 10 \mu \mathrm{M}$ & $98 \pm 13,58$ & 96 & 29 & 0,139 & $73 \pm 4,98$ & 69 & 10 & 0,068 \\
\hline Analog $3 f 10 \mu \mathrm{M}$ & $101 \pm 6,83$ & 98 & 15 & 0,068 & $71 \pm 7,77$ & 69 & 21 & 0,109 \\
\hline Kontrola $+\mathrm{B}[a] \mathrm{P}$ & $77 \pm 4,66$ & 77 & 13 & 0,061 & $75 \pm 7,73$ & 76 & 19 & 0,103 \\
\hline
\end{tabular}

FAU — umowne jednostki fluorescencji Rod-123; $\bar{\chi} \pm$ s.d. — średnia arytmetyczna \pm odchylenie standardowe; Med. — mediana; $R$ — rozstęp; $Y$ — współczynnik zmienności

Tabela IVB. Test- $t$ w ocenie istotności statystycznej wyników otrzymanych w teście akumulacji Rod-123

1. Ocena istotności różnic akumulacji Rod-123 w hodowlach z badanymi związkami, niepreinkubowanych z FB $F_{1}\left(-F_{1}\right)$ lub preinkubowanych z FB $\left(+\mathrm{FB}_{1}\right)$ i w odpowiednich kontrolach

\begin{tabular}{|c|c|c|c|c|c|c|c|c|}
\hline \multirow[t]{3}{*}{ Test- $t$ (p) } & \multicolumn{4}{|c|}{$-\mathrm{FB}_{1}$} & \multicolumn{4}{|c|}{$+\mathrm{FB}_{1}$} \\
\hline & $\begin{array}{c}\text { Kontrola } \\
+\mathrm{B}[a] \mathrm{P}\end{array}$ & $\begin{array}{c}\mathrm{FPh} \\
10 \mu \mathrm{M}\end{array}$ & $\begin{array}{c}\text { Analog 1b } \\
10 \mu \mathrm{M}\end{array}$ & $\begin{array}{c}\text { Analog } 3 f \\
10 \mu \mathrm{M}\end{array}$ & $\begin{array}{c}\text { Kontrola } \\
+\mathrm{B}[a] \mathrm{P}\end{array}$ & $\begin{array}{c}\mathrm{FPh} \\
10 \mu \mathrm{M}\end{array}$ & $\begin{array}{c}\text { Analog 1b } \\
10 \mu \mathrm{M}\end{array}$ & $\begin{array}{c}\text { Analog } 3 f \\
10 \mu \mathrm{M}\end{array}$ \\
\hline & - & 0,$081 ; N S^{*}$ & 0,032 & 0,006 & - & 0,028 & 0,$663 ; N S$ & 0,$471 ; N S$ \\
\hline
\end{tabular}

2. Ocena istotności różnic akumulacji Rod-123 w hodowlach bez $F_{1}\left(-F_{1}\right)$ lub z FB $F_{1}\left(+F_{1}\right)$ i z poszczególnymi badanymi związkami

\begin{tabular}{lccc}
\hline & \multicolumn{3}{c}{ Test- $t(\mathrm{p})$} \\
\cline { 2 - 4 } & $\begin{array}{c}\mathrm{FPh} \\
10 \mu \mathrm{M}\end{array}$ & $\begin{array}{c}\text { Analog } 1 \mathrm{~b} \\
10 \mu \mathrm{M}\end{array}$ & $\begin{array}{c}\text { Analog } 3 \mathrm{f} \\
10 \mu \mathrm{M}\end{array}$ \\
\hline $\begin{array}{l}-\mathrm{FB}_{1} \\
+\mathrm{FB}_{1}\end{array}$ & 0,$103 ; N S$ & 0,029 & 0,005 \\
\hline
\end{tabular}

${ }^{*} N S$ - nieistotne statystycznie 
Tabela V. Współczynniki $W_{\mathrm{apo}}, \mathrm{W}_{\mathrm{AAU}}$ i $\mathrm{W}_{\mathrm{FAU}}$ dla badanych związków

\begin{tabular}{lccc} 
& \multicolumn{3}{c}{ Badane związki } \\
\cline { 2 - 4 } & $\mathrm{FPh}$ & Analog 1b & Analog $3 f$ \\
$10 \mu \mathrm{M}$ & $10 \mu \mathrm{M}$ & 0,9041 & 0,7625 \\
\hline $\mathrm{W}_{\text {apo }}$ & $1 ; N S$ & 0,$8323 ; N S$ & 0,$8063 ; N S$ \\
$\mathrm{~W}_{\text {AAU }}$ & 0,$9737 ; N S$ & 0,7737 & 0,7299 \\
$\mathrm{~W}_{\text {FAU }}$ & 1,$1217 ; N S$ & & \\
\hline
\end{tabular}

*NS - nieistotne statystycznie

Z tabeli V widać, że aktywność chemoprewencyjna analogów 1 b i 3 wymaga aktywnej CerS. Natomiast dla FPh nie wykazano zależności jej efektu chemoprewencyjnego od obecności CerS. Ponadto tabela V pokazuje, że w przypadku wszystkich badanych związków aktywność wykonawczej Casp-3 w hodowlach limfocytów $(+\mathrm{B}[a] \mathrm{P})$ z zablokowaną CerS $\left(+\mathrm{FB}_{1}\right)$ była porównywalna do aktywności Casp-3 w hodowlach limfocytów $(+\mathrm{B}[a] \mathrm{P})$ bez $\mathrm{FB}_{1}\left(-\mathrm{FB}_{1}\right)$.

\section{Podsumowanie}

Na podstawie wyników badań własnych oceniono udział CerS, jednego zgłównych enzymów szlaku syntezy cer denovo, w efektach proapoptotycznym i chemouwrażliwiającym FPh oraz jej analogów: związków 1b i 3 f w hodowlach limfocytów uszkodzonych przez B[a]P. Należy kontynuować badania in vitro z wykorzystaniem inhibitorów także innych enzymów uczestniczących w syntezie cer de novo, np. myriocyny (inhibitor SPT), aby dokładnie poznać mechanizm działania chemoprewencyjnego/przeciwnowotworowego badanych analogów FPh oraz określić ich wpływ na gospodarkę sfingolipidową komórek uszkodzonych genotoksycznie [34, 35].

\section{Wnioski}

1. Efekty: proapoptotyczny i chemouwrażliwiający nowo syntezowanych analogów flufenazyny — związków 1 b i 3 f są uwarunkowane aktywacją CerS.

2. Działanie proapoptotyczne analogów 1b i 3f zależne od CerS nie wymaga aktywacji wykonawczej Casp-3.

3. Dla macierzystej FPh wykazano, że jej aktywność chemoprewencyjna nie zależy od stymulacji szlaku syntezy de novo cer z udziałem CerS.

\section{Konflikt interesu: nie zgłoszono}

\section{Dr Agata Jaszczyszyn}

Katedra Podstaw Nauk Medycznych

Uniwersytet Medyczny im. Piastów Śl.

ul. Borowska 211, 50-556 Wrocław

e-mail:agata.jaszczyszyn@umed.wroc.pl

Otrzymano: 3 stycznia 2013 r.

Przyjęto do druku: 4 kwietnia 2013 r.

\section{Piśmiennictwo}

1. Mo W, Hang JT. Human ABCG2: structure, function, and its role w multidrug resistance. Int J Biochem Mol Biol 2012; 3: 1-27.
2. Śliwińska-Hill U, Trocha J. Najnowsze terapie przeciwnowotworowe. Post Farm 2011; 1: 14-19.

3. Malinowska K, Modranka R, Kędziora J. Leki przeciwnowotworowe stosowane w lecznictwie oraz będące $w$ fazie badań klinicznych. Pol Merk Lek 2007; 23: 165-169.

4. Łyskawa W. Chemioterapia w leczeniu choroby nowotworowej i jej neurotoksyczność. Anest Ratow 2009; 3: 80-87.

5. Singh P, Singh A. Ocular adverse effects of anti-cancer chemotherapy and targeted therapy. J Canc Ther Res 2012; 1. (www. hoajonline. com/journals/jctr/content/pdf/5.pdf).

6. Monsuez JJ. Charniot JCh, Vignat N i wsp. Cardiac side-effect of cancer chemotherapy. Int J Cardiol 2010; 144: 3-15.

7. SarosiekT, Żołnierek J, Langiewicz P i wsp. Chemioterapia wysokodawkowa guzów zarodkowych - koniec czy początek drogi? Współcz Onkol 2002; 6: 434-450.

8. Boffetta P, Kaldor JM. Secondary malignancies following cancer chemotherapy. Acta Oncol 1994; 33: 591-598.

9. Shen F, Chu S, Bence AK i wsp. Quantitation of doxorubicine uptake, efflux, and modulation of multidrug resistance (MDR) in MDR human cancer cells. JPET 2008; 324: 95-102.

10. Huang C, Xu D, Xia Q i wsp. Reversal of P-glycoprotein-mediated multidrug resistance of human hepatic cancer cells by Astragaloside II. J Pharm Pharmacol 2012; 64: 1741-1750.

11. Huszno J, Nowara E, Suwiński R. Znaczenie polimorfizmów genowych w chemioterapii nowotworów. Nowotwory J Oncol 2011; 61: 141-149.

12. Karikas GA. Chemoprevention molecular and biochemical mechanism involved in cancer control and management. Health Sci J 2011; 5: 149-156.

13. Thangapazham RL, Sharma A, Maheshwari RK. Multiple molecular targets in cancer chemoprevention by curcumin. AAPS J 2006; 8: E443-449.

14. Jaszczyszyn A, Gasiorowski K, Świątek P i wsp. Wpływ nowo syntezowanych analogów flufenazyny na apoptozę i nekrozę w hodowlach limfocytów. Onkol Pol 2009; 14: 143-149.

15. Jaszczyszyn A, Gąsiorowski K, Swiątek Pi wsp. Analog in chemoprevention of late cancer. W: Krzyżanowski D, Krakowiak P, Binnebesel J, Fal AM, Steciwko A, (red.). Live with dignity to the end. Clinical and social aspects o palliative and hospice care. T. 3. Opole: Publishing Mouse WCM; 2011, s. $152-165$.

16. Wang XW, Wang XK, Zhang X i wsp. FG020326 sensitized multidrug resistance cancer cells to docetaxel-mediated apoptosis via enhancement of caspases activation. Molecules 2012; 17: 5442-5458.

17. Patwardhan GA, Liu YY. Sphingolipids and expression regulation of genes in cancer. Prog Lipid Res 2011; 50: 104-114.

18. Chapman JV, Gouazé-Andersson V, Karimi R i wsp. P-glycoprotein antagonists confer synergistic sensitivity to short-chain ceramide in human multidrug-resistant cancer cells. Exp Cell Res 2011; 317: 1736-1745.

19. Jaszczyszyn A, Gąsiorowski K. Mechanizmy chemoprewencyjnego działania nowo syntezowanych analogów flufenazyny. Warszawa: Wydawnictwo Medyczne Borgis'; 2006.

20. Gąsiorowski K, Jaszczyszyn A. Fenotiazyny w paliatywnej terapii nowotworów. Onkol Pol 2008; 11: 171-175.

21. Jaszczyszyn A, Gasiorowski K, Świątek P i wsp. Chemical structure of phenothiazines and their biological activity. Pharmacol Rep 2012; 64: 16-23.

22. Jaszczyszyn A, Gasiorowski K, Świątek P i wsp. New fluphenazine analogues as inhibitor of P-glycoprotein in human lymphocyte cultures. Współcz Onkol 2012; 16: 332-337.

23. Petrus J, Czarnik-Matusewicz B, Jaszczyszyn A i wsp. Influence of fluphenazine dihydrochloride on model dipalmitoylphosphatidylcholine membranes and human genotoxically damaged lymphocyte cultures. Curr Issues Pharm Med Sci 2012; 25: 270-273.

24. Jaszczyszyn A, Gąsiorowski K, Świątek P i wsp. The chemosensitive activity of new fluphenazine analogues in human lymphocyte cultures after acid sphingomyelinase blockade. W: J Physiol Pharmacol 2011; 62 (suppl.1): 45. Okrasa S, Kotwica G, Wojciechowicz B, (red.). Book of programme and abstracts. 25th Congress of the Polish Physiological Society; 15-17 Sept. 2011; Olsztyn, Poland.

25. Jaszczyszyn A, Gąsiorowski K, Świątek P i wsp. Aktywność proapoptotyczna analogów flufenazyny po zablokowaniu sfingomielinaz w hodowlach limfocytów ludzkich. Onkol Pol 2011; 14: 54-63.

26. Senchenkov A, Litvak DA, Cabot MC. Targeting ceramide metabolism - a strategy for overcoming drug resistance. J Natl Cancer Inst 2001; 93: 347-357.

27. Modrak DE, Gold DV, Goldenberg DM. Sphingolipid targets in cancer therapy. Mol Cancer Ther 2006; 5: 200-208.

28. Boyum A. Separation of leukocytes from blood and bone marrow. Scand JClin Lab Invest 1968: 21:77-89.

29. Zitomer NC, Mitchell T, Voss KA i wsp. Ceramide synthase inhibition by fumonisin $B_{1}$ causes accumulation of 1-deoxysphinganine. J Biol Chem 2009; 284: 4786-4795.

30. Schroeder JJ, Crane HM, Jianhui X i wsp. Disruption of sphingolipid metabolism and stimulation of DNA synthesis by fumonisin $\mathrm{B}_{1} . \mathrm{J}$ Biol Chem 1994; 269: 3475-3481.

31. Li J, Yuan J. Caspases in apoptosis and beyond. Oncogene 2008; 27: 6194-6206.

32. Portt L, Norman G, Clapp C i wsp. Anti-apoptosis and cell survival: a review. Biochim Biophys Acta 2010; 1813: 238-259.

33. Korzeniewska-Dyl I. Kaspazy - struktura i funkcja. Pol Merkuriusz Lek 2007; 23: 403-407.

34. LeeYS, Choi KM, Lee Si wsp. Myriocin, a serine palmitoyltransferase inhibitor, suppresses tumor growth in a murine melanoma model by inhibiting de novo sphingolipid synthesis. Cancer Biol Ther 2012; 13: 92-100.

35. Schmitz A. Metabolity sfingomielin w przekazywaniu sygnałów komórkowych i w miażdżycy. Czyn Ryz 2004; 1-2: 38-51. 